\title{
PENGARUH PEMBELAJARAN KOOPERATIF TIPE THINK-PAIR-SHARE (TPS) DAN NUMBERED-HEADS-TOGETHER (NHT) TERHADAP MOTIVASI DAN HASIL BELAJAR MATEMATIKA
}

\author{
Gunawan Maryoto \\ SMP N I Prigen Kabupaten Pasuruan \\ e-mail: maryotogunawans2@gmail.com
}

\begin{abstract}
This quasi - experimental research aims to determinethe effect of cooperative learning model Think Pair Share (TPS) and Numbered Heads Together (NHT) on students' mathematics achievement, and the effect ofcooperative learning model TPSand NHT on student motivation. Three classes were randomly selected for experiment and control groups, each class consists of 32 students. A questionnaire of 26 items is used to measure motivation test, and a test consisting of nine questions is used for measuring mathematics achievement. T-test was used for data analysis. The findings show that there is significant effect of both cooperative learningTPS model and NHT model onstudent mathematics achievement. However, the effect of TPS and NHT models on student motivation to learn mathematics is not significant.
\end{abstract}

Keywords: mathachievement, motivation, think-pair-share model, numbered-headstogether model

\begin{abstract}
ABSTRAK
Penelitian ini dimaksudkan untuk menganalisis pengaruh pembelajaran kooperatif tipe TPS dan tipe NHT terhadap motivasi dan hasil belajar matematika. Penelitian ini melibatkan 3 kelas experimen dan kelas control, masing-masing terdiri dari 32 siswa. Instrumen yang digunakan berupa tes motivasi yang terdiri dari 26 indikator, dan tes matematika yang terdiri dari 9 pertanyaan. Hasil penelitian menunjukkan bahwa terdapat pengaruh yang signifikan penggunaan model pembelajaran kooperatif tipe TPS terhadap hasil belajar matematika siswa, demikian pula penggunaan model pembelajaran kooperatif tipe $\mathrm{NHT}$ juga berpengaruh positif terhadap hasil belajar matematika siswa. Namun tidak ada perbedaan signifikan hasil belajar matematika menggunakan model pembelajaran kooperatif tipe TPS dengan model pembelajaran kooperatif tipe NHT. Di samping itu ditemukan pengaruh yang signifikan penggunaan model pembelajaran kooperatif tipe TPSdan Tipe NHT terhadap motivasi belajar matematika siswa.
\end{abstract}

Kata kunci: hasil belajar matematika, motivasi, think pair share, numbered-heads-together 
Pendidikan selalu diperhadapkan dengan tantangan untuk menyelenggarakan pembelajaran yang mampu memberikan pengalaman belajar yang bermakna bagi siswa dan menghasilkan lulusan yang memiliki penguasaan pengetahuan yang baik. Pemanfaatan beragam metode pembelajaran berdasarkan prinsip-prinsip pembelajaran tertentu akan memberi peluang lebih besar untuk mncapai capaian belajar yang diharapkan.

Matematika mempunyai peranan yang penting dalam perkembangan ilmu pengetahuandan teknologi karena memberikan landasan berpikir matematis, oleh sebab itu kemampuan matematis ini perlu dikembangkan sejak dini pada anak. Namun demikian ternyata hasil belajar matematika di berbagai sekolah dinilai belum mencapai hasil yang diharapkan. Banyak siswa yang masih menganggap matematika merupakan pelajaran yang sulit, di samping itumotivasi siswa untuk belajar matematika juga masih rendah. Rendahnya motivasi siswa dalam belajar matematika dapat dilihat dari rendahnya antusias siswa untukbelajarmatematika. Dalam pembelajaran kelas matematika, seringkali hanya sedikit siswa yang menanggapi dan menjawab pertanyaan guru, dan sedikit pula siswa yang bertanya kepada guru bila menemukan materi pelajaran yang belum dipahami.

Slameto (2010:134) memberikan penjelasan bahwa faktor motivasi sangat penting dalam belajar siswa. Di samping itu proses yang mendorong kerjasama antar siswa juga mempengaruhi hasil belajar siswa. Slavin (sebagaimana dikutip dalam Arends1997) melaporkan bahwa 45 penelitian telah dilakukan antara tahun 1972 dan 1986 untuk menyelidiki efek pembelajaran kooperatif pada prestasi. Hasil penelitian menunjukkan bahwa kelas pembelajaran kooperatif sebagai kelas eksperimen secara signifikan mengungguli kelas kelompok kontrol dalam prestasi akademik. Keuntungan lain metode belajar kooperatif menurut Anita Lie (2002:91) adalah bahwa metode cooperative learning menimbulkan suasana positif yang kondusif dalam membangun kecintaan anak pada pelajaran dan sekolah. Dan dalam kegiatan-kegiatan bersama dalam cooperative learning, siswa lebih terdorong untuk belajar dan berpikir.

Pembelajaran kooperatif mempunyai beberapa variasi diantaranya model kooperatif tipe Think Pair Share (TPS) dan Numbered Head Together (NHT). Setiap model pembelajaran mempunyai kelebihan dan kekurangan, demikian juga model TPS dan NHT. Model pembelajaran Kooperatif Tipe TPS yang lebih fokus pada berpikir secara berpasangan dapat menjadikan siswa mudah untuk berinteraksi dengan orang lain, menghargai setiap perbedaan yang ada dan siswa dapat bertanggung jawab dalam belajar. Namun model pembelajaran kooperatif tipe TPS juga mempunyai kekurangan yaitu membutuhkan waktu yang lebih banyak sehingga dikhawatirkan materi yang akan disampaikan tidak dapat selesai sesuai waktu yang ditentukan. Kelebihan model kooperatif tipe NHT adalah siswa dapat mengetahui materi mana yang belum dipahami sehingga akan berusaha untuk bertanya kepada guru atau siswa yang lain. Namun model kooperatif Tipe NHT juga membutuhkan waktu yang lama. Namun seharusnya guru lebih mementingkan proses belajar yang dapat membangun kemampuan-kemampuan siswa yang strategis untuk pengembangan diri selanjutnya, dibandingkan dengan cakupan materi bahasan di kelas.

Penelitian ini mempunyai beberap tujuan, yaitu: (1) mendiskripsikan pengaruh pembelajaran kooperatif tipe TPS terhadap hasil belajar,(2) mendiskripsikan pengaruh pembelajaran kooperatif tipe NHT terhadap hasil belajar, (3) mendiskripsikan perbedaan hasil belajar pembelajaran kooperatif tipe TPS dan tipe NHT,(4) mendiskripsikan pengaruh pembelajaran kooperatif tipe TPS terhadap motivasi siswa, (5) mendiskripsikan pengaruh yang signifikan Pembelajaran kooperatif tipe NHT terhadap motivasi siswa, dan (6) mendiskripsikan perbedaan motivasi belajar pembelajaran kooperatif tipe TPS dan tipe NHT. Pokok bahasan yang akan digunakan dalam penelitianj ini adalah tentang relasi dan fungsi. 
Untuk mencapai tujuan pembelajaran matematika diperlukan kondisi pembelajaran yang menarik, interaksi multi arah,dan penggunaan metode pembelajaran yang bervariasi, di antaranya metode kooperatif. Hal-hal tersebut dapat memberi dorongan dan menumbuhkan motivasi peserta didik untuk mempelajari materi pelajaran dengan baik. Eggen dan Kauchak (sebagaimana dikutip dalam Trianto:2011) menyatakan pembelajaran kooperatif merupakan strategi pembelajaran yang melibatkan siswa dalam bekerjasama dan kolaborasi untuk mencapai tujuan bersama.Hasil penelitian yang dilakukan Linda Lungren (sebagaimana dikutip dalam Ibrahim dkk, 2000:18) menunjukkan bahwa dalam setting kelas kooperatif, siswa belajar lebih banyak dari teman yang lain daripada dari guru. Penelitian ini juga menunjukkan bahwa pembelajaran kooperatif memiliki dampak yang positif terhadap siswa yang semula hasil belajarnya rendah. Dengan demikian dapat disimpulkan bahwa pembelajaran kooperatif merupakan pembelajaran inovatif yang dapat digunakan oleh guru untuk sekaligus meningkatkan hasil belajar dan aktivitas siswa, serta memberi iklim yang kondusif dalam perkembangan daya nalar dan kreatifitas siswa, termotivasi untuk belajar menyampaikan pendapat dan bersosialisasi dengan teman.

Pembelajaran kooperatif mempunyai beberapa variasi. Diantaranya adalah pendekatan struktural yang meliputi TPS dan NHT. Think Pair share atau berpikir berpasangan berbagi adalah jenis pembelajaran kooperatif yang dirancang untuk mempengaruhi pola interaksi siswa. Menurut Arends (1997) TPS ini berkembang dari penelitian belajar kooperatif dan waktu tunggu. Dengan asumsi bahwa semua resitasi atau diskusi membutuhkan pengaruh untuk mengendalikan kelas secara keseluruhan, dan prosedur yang digunakan dalam TPS dapat memberi siswa lebih banyak waktu untuk berpikir, untuk merespon dan saling membantu.

Kelebihan kooperatif tipe NHT menurut Lie (2005) adalah: siswa belajar berpasangan, lebih banyak ide yang muncul dalam diskusi, lebih banyak tugas yang dilakukan, dan guru lebih mudah untuk memonitor. Sedangkan kekurangan model Kooperatif Tipe NHTadalah: membutuhkan lebih banyak waktu, membutuhkan sosialisasi yang lebih lama, kekurangan waktu untuk kontribusi individu, dan siswa tidak mudah mempertahankan konsentrasi pada belajar.

Sardiman (1990:75) menyatakan bahwa motivasi belajar adalah keseluruhan daya penggerak dalam diri siswa yang menimbulkan kegiatan belajar, menjamin kelangsungan dan memberikan arah pada kegiatan belajar untuk mencapai tujuan subyek belajar. Dalam belajar, motivasi siswa sangat penting untuk berhasil, sehingga motivasi dalam belajar tersebut perlu dibangun.

Hasil penelitian sebelumnya menunjukkan bahwa pembelajaran kooperatif tipe NHT maupun tipe TPS berpengaruh secara signifikan terhadap hasil belajar dan motivasi siswa. Untuk itu penelitian ini akan mengkaji pengaruh model pembelajaran tersebut khusunya dalam pembelajaran matematika. Hipotesis yang diajukan dalam penelitian ini adalah sebagai berikut: 1) terdapat pengaruh yang signifikan pembelajaran kooperatif tipe TPS terhadap hasil belajar materi relasi dan fungsi, 2) terdapat pengaruh signifikan pembelajaran kooperatif tipe NHT terhadap hasil belajar materi relasi dan fungsi, 3) ada perbedaan hasil belajar menggunakan pembelajaran kooperatif tipe TPS dan tipe NHT dalam materi relasi dan fungsi, 4) terdapat pengaruh yang signifikan pembelajaran kooperatif tipe TPS terhadap motivasi siswa, 5) terdapat pengaruh yang signifikan Pembelajaran kooperatif tipe NHT terhadap motivasi, dan 6) terdapat perbedaan motivasi belajar matematika dalam penggunaan pembelajaran kooperatif tipe TPS dan tipe NHT. 


\section{METODE}

Desain penelitian yang digunakan dalam penelitian ini adalah kuasi eksperimen. Pada penelitian ini digunakan rancangan non acak dengan pra tes dan post test dengan kelompok kontrol ( Non randomPre-test - Post-test Control Group Design). Penelitian ini menggunakan tiga model pembelajaran yang berbeda yaitu model kooperatif tipe TPS, model pembelajaran kooperatif tipe NHT dan pembelajaran konvensional. Rancangan eksperimennya disajikan pada Tabel 1.

Tabel 1. Rancangan Eksperimen

\begin{tabular}{lccc}
\hline \multicolumn{1}{c}{ Kelompok } & Pretes & Perlakuan & Postes \\
\hline Ekperimen-1 & $\mathrm{T}_{1}$ & $\mathrm{X}_{1}$ & $\mathrm{~T}_{2}$ \\
Eksperimen-2 & $\mathrm{T}_{1}$ & $\mathrm{X}_{2}$ & $\mathrm{~T}_{2}$ \\
Kontrol & $\mathrm{T}_{1}$ & 0 & $\mathrm{~T}_{2}$ \\
\hline
\end{tabular}

$\begin{array}{ll}\text { Keterangan: } & \mathrm{X}_{1}=\text { Kooperatif-TPS } \\ & \mathrm{X}_{2}=\text { Kooperatif-NHT } \\ 0 & =\text { Konvensional } \\ \mathrm{T}_{1} & =\text { pre test } \\ \mathrm{T}_{2} & =\text { post test }\end{array}$

Populasi penelitianini adalah siswa kelas VIIIA,B,C,D, dan E, SMP Negeri 1 Prigen Kabupaten Pasuruan yang berjumlah 162 siswa. Dari lima kelas yang diambil sebagai populasi yaitu kelas VIII A,B,C,D, dan E diuji homogenitas dengan menggunakan uji Lavene dengan hasil nilai signifikansi 0,416. Karena nilai signifikansinya lebih besar dari 0,05 maka dapat disimpulkan bahwa tidak ada perbedaan varians dari kelima kelas tersebut. Berdasarkan kondisi populasi yang homogen maka pengambilan sampel dalam penelitian ini menggunakan teknik klaster. Dari populasi diambil 3 kelas sebagai sampel secara acak. Dalam hal ini sehingga diperoleh sampel dalam penelitian ini adalah siswa kelas VIII-IA, VIII-B dan VIII-D SMP Negeri 1 Prigen.

Dalam penelitian ini digunakan empat macam instrumen yang meliputi: instrumen yang berfungsi sebagai pendukung pembelajaran dalam kelas Matematika, yaitu Rencana Pelaksanaan Pembelajaran (RPP) dan LKS, dan instrumen yang digunakan untuk mengukur variabel terikat yaitu tes hasil belajar dan angket motivasi belajar. Instrumen tes berupa soal tes uraian untuk memperoleh data tentang prestasi belajar matematika siswa. Ada dua jenis tes yang digunakan dalam penelitian ini, yaitu tes kemampuan awal (pre test), dan tes kemampuan akhir (post test). Prosedur pengembangan tes hasil belajar yang digunakan adalah sebagai berikut: (1) menyusun kisi-kisi tes hasil belajar,(2) menyusun butir soal dan menelaahnya,(3)validasi ahli, (4) revisi soal,(5) ujicoba instrumen tes hasil belajar, dan (6) analisis data ujicoba.

Tes terdiri atas 9 soal dengan skor maksimum yang diharapkan 60 dan skor minimumnya 0 . Materi soal pre test dan post test adalah tentang 'relasi dan fungsi.'

Instrumen yang baik harus memenuhi dua pesyaratan yaitu validitas dan reliabilitas instrumen. Untuk memperoleh validitas isi maka instrumen dikonsultasikan kepada para ahli (expert judgment). Untuk mengetahui validitas secara empirik dipergunakan perhitungan rumus korelasi Product Moment dari Pearson, dan diperoleh hasil bahwa diantara 9 butir soal tidak terdapat butir soal yang gugur. Setelah dilakukan perhitungan reliabilitas dengan menggunakan program SPSS diperoleh $r_{\text {hitung }}=0,0,809>0,329=r_{\text {tabel }}$ dengan $\alpha=0,05$ dan $\mathrm{dk}=34$. Dalam hal ini koefisien reliabilitas instrumen termasuk dalam kriteria reliabilitas tinggi. 
Pada angket motivasi siswa, setelah dilakukan perhitungan rumus korelasi Product Moment dari Pearson diperoleh hasil bahwa diantara 32 butir angket motivasi terdapat 6 butir yang gugur. Setelah dilakukan perhitungan reliabilitas diperoleh $r_{\text {hitung }}=0,896>0,329=r_{\text {tabel }}$ dengan $\alpha=0,05$ dan $\mathrm{dk}=34$. Dalam hal ini koefisien reliabilitas instrumen termasuk dalam kriteria tinggi.

Pengumpulan data dibagi menjadi tiga tahap. Tahap pertama adalah pre test pada kelompok eksperimen dan kontrol. Tahap kedua adalah perlakuan pada kelompok eksperimen menggunakan pembelajaran kooperatif dan perlakuan pada kelompok kontrol menggunakan pembelajaran konvensional. Tahap ketiga adalah post test pada kelompok eksperimen dan kontrol setelah mempelajari materi relasi dan fungsi. Dengan demikian data yang diperlukan dikumpulkan dengan dua macam cara yaitu tes dan angket. Sedangkan tahap-tahap analisis data dilakukan melalui analisis deskriptif untuk mendeskripsikan data, uji asumsi analisis, dan uji hipotesis dengan menggunakan uji $t$-student.

\section{TEMUAN DAN PEMBAHASAN}

\section{Hasil Belajar}

Post test diberikan pada kelas eksperimen dan kelas kontrol untuk mengetahui bagaimana kemampuan akhir siswa setelah mendapat perlakuan. Data Selisih Pre test-Post test diperoleh dari masing-masing kelas yang terdiri dari 32 siswa. Skor yang diberikan mempunyai rentang 0-60. Dari hasil pengolahan data untuk masing-masing kelas diperoleh nilai maksimum, nilai minimum, nilai rerata dan simpangan baku seperti terdapat pada Tabel 2 .

Tabel 2. Nilai Maksimum, Nilai Minimum, Rerata, dan Simpangan Baku Data Selisih Pre test-Post test Kelas Eksperimen dan Kelas Kontrol.

\begin{tabular}{lccccc}
\hline \multirow{2}{*}{ Kelas } & \multicolumn{5}{c}{ Selisih Pre test-Post test } \\
\cline { 2 - 6 } & $\mathrm{N}$ & Maksimum & Minimun & Rerata & $\begin{array}{c}\text { Simpangan } \\
\text { Baku }\end{array}$ \\
\hline Eksperimen1 (TPS) & 32 & 52,00 & 22,00 & 38,20 & 6,52 \\
Eksperimen2 (NHT) & 32 & 54,00 & 25,00 & 41,25 & 8,19 \\
Kontrol (konvensional) & 32 & 42,50 & 22,50 & 32,35 & 6,27 \\
\hline
\end{tabular}

Berdasarkan hasil uji normalitas dan uji homogenitas diperoleh bahwa data berdistribusi normal dan homogen, sehingga dapat dilanjutkan uji kesamaan rata-rata dengan menggunakan uji t satu pihak melalui program SPSS 21 for Windows menggunakan Independent Sample t-test dengan asumsi kedua varians homogen (equal variances assumed) dengan taraf signifikansi 0,05.

Dari hasil $t$ test for equality of means, Levene Test diperoleh sig. $=0,001$ lebih kecil dari 0,05. Ini berarti hipotesis nol ditolak, dan bahwa terdapat perbedaan rata-rata kedua kelas. Pada kolom mean difference tercantum rata-rata perbedaan mean skor selisih pre test-post test adalah $-5,85156$ ini berarti kelompok Ekseperimen-1. memiliki rata-rata yang lebih baik dari kelompok kontrol. Hal ini berarti bahwa hasil belajar matematika siswa yang menggunakan model pembelajaran Kooperatif Tipe TPS lebih baik daripada hasil belajar matematika siswa yang menggunakan pembelajaran konvensional.

Dari hasil $t$ test for equality of means diperoleh sig. $=0,000$ lebih kecil dari 0,05 . Ini berarti hipotesis nol ditolak, dan bahwa terdapat perbedaan rata-rata kedua kelas. Pada kolom mean difference tercantum rata-rata perbedaan mean skor selisih pre test - post test adalah -8,89844 ini 
berarti kelompok Ekseperimen-2. memiliki rata-rata yang lebih baik dari kelompok kontrol. Hal ini berarti bahwa hasil belajar matematika siswa yang menggunakan model pembelajaran Kooperatif Tipe NHT lebih baik daripada hasil belajar matematika siswa yang menggunakan pembelajaran konvensional.

Dari hasil $t$ test for equality of means diperoleh sig. $=0,105$ lebih besar dari 0,05 . Ini berarti hipotesis nol tidak ditolak, dan bahwa tidak terdapat perbedaan signifikan antara rata-rata kedua kelas. Pada kolom mean difference tercantum rata-rata perbedaan mean skor selisih pre test-post test adalah -3,04688 ini berarti kelompok Eksperimen-2 memiliki rata-rata yang lebih baik dari kelompok Eksperimen-1, meskipun tidak berbeda secara signifikan.

Temuan penelitian ini selaras dengan penelitian Daulay Hamidah (2013) bahwa pembelajaran kooperatif tipe TPS dapat digunakan untuk meningkatkan hasil belajar siswa. Hal ini juga selaras dengan penelitian Ylyas Sopyyev (2013) bahwa rata-rata hasil belajar siswa dengan model pembelajaran TPSlebih baik dari pada pembelajaran ekpsositori pada materi pokok fungsi. Hasil uji kesamaan rerata dengan ujit dan didapatkan hasil bahwa hasil belajar matematika siswa yang menggunakan model pembelajaran kooperatif tipe NHTlebih baik daripada siswa yang menggunakan pembelajaran konvensional. Hal ini selaras dengan hasil penelitian Anesia Dyah Widayanti (2013) bahwa ada pengaruh model pembelajaran kooperatif tipe Numbered Heads Together (NHT) terhadap hasil belajar siswa kelas VII MTs Negeri Karangrejo Tulungagung.

\section{Motivasi Belajar}

Dalam penelitian ini, pengukuran motivasi belajar dilakukan sebelum pembelajaran materi relasi dan fungsi dimulai dan setelah pembelajaran relasi dan fungsi berakhir. Dengan menggunakan model pembelajaran (perlakuan) yang berbeda pada ketiga kelas. Pada kelas eksperimen-1 diberi perlakuan dengan menggunakan model pembelajaran Kooperatif Tipe TPS , Pada kelas eksperimen2 diberi perlakuan dengan menggunakan model pembelajaran Kooperatif Tipe NHT sedangkan pada kelas kontrol menggunakan pembelajaran konvensional atau pembelajaran biasa.

Setelah diberikan perlakuan yang berbeda, maka diadakan pengukuran motivasi akhir pada akhir pembelajaran. Analisis data motivasi belajar bertujuan untuk mengetahui bagaimana pengaruh ketiga model pembelajaran terhadap hasil motivasi belajar siswa, apakah lebih baik daripada siswa yang menggunakan pembelajaran konvensional ataukah sebaliknya.

Angket untuk mengukur motivasi diberikan pada kelas eksperimen dan kelas kontrol untuk mengetahui bagaimana motivasi siswa pada kedua kelas setelah mendapat perlakuan. Data motivasi diperoleh dari masing-masing kelas yang terdiri dari 32 siswa. Skor yang diberikan mempunyai rentang 1-5 tiap butir.

Tabel 3. Selisih Maksimum, Minimum, Rerata, dan Simpangan Baku Data Selisih Skor Motivasi Kelas Eksperimen dan Kelas Kontrol

\begin{tabular}{lrcrrc}
\hline \multirow{2}{*}{ Kelas } & \multicolumn{5}{c}{ Motivasi akhir } \\
\cline { 2 - 6 } & $\mathrm{N}$ & $\begin{array}{c}\text { Selisih } \\
\text { Maksimum }\end{array}$ & $\begin{array}{c}\text { selisish } \\
\text { Minimun }\end{array}$ & Rerata & $\begin{array}{c}\text { Simpangan } \\
\text { Baku }\end{array}$ \\
\hline Eksperimen1 (TPS) & 32 & 13 & -10 & 3,75 & 5,864 \\
Eksperimen2 (NHT) & 32 & 14 & -3 & 5,00 & 4,833 \\
Kontrol (konvensional) & 32 & 13 & -10 & $-0,75$ & 5,124 \\
\hline
\end{tabular}


Berdasarkan hasil uji normalitas dan uji homogenitas diperoleh bahwa data berdistribusi normal dan homogen, sehingga dapat dilanjutkan uji kesamaan rata-rata dengan menggunakan uji t satu pihak melalui program SPSS 21 for Windows menggunakan Independent Sample T-Test dengan asumsi kedua varians homogen (equal varians assumed) dengan taraf signifikansi 0,05.

Dari hasil $t$ test for equality of Means kelas eksperimen 1 dan kelas kontrol diperoleh sig.= 0,002 lebih kecil dari 0,05 . Ini berarti hipotesis nol ditolak, dan bahwa terdapat perbedaan rata-rata kedua kelas. Pada kolom mean difference tercantum rata-rata perbedaan mean skor selisih motivasi awal-motivasi akhir adalah -4,500 ini berarti kelompok Ekseperimen-1. memiliki rata-rata yang lebih baik dari kelompok kontrol.

Dari hasil $t$ test for equality of Meanskelas eksperimen 2 dan kelas kontrol diperoleh sig. $=0,000$ lebih kecil dari 0,05 . Ini berarti hipotesis nol ditolak, dan bahwa nilai rata-rata kedua kelas berbeda secara signifikan. Pada kolom mean difference tercantum rata-rata perbedaan mean skor selisih motivasi awal-motivasi akhir adalah -5,750 ini berarti kelompok Ekseperimen-2. memiliki rata-rata yang lebih baik dari kelompok kontrol. Hal ini berarti bahwa motivasi siswa pada kelas yang menggunakan model pembelajaran Kooperatif Tipe NHT lebih baik daripada motivasi siswa yang menggunakan pembelajaran konvensional.

Dari hasil $t$ test for equality of meansnilai motivasi kelas eksperimen 1 dan eksperimen 2 diperoleh sig. $=0,356$ lebih besar dari 0,05 . Ini berarti hipotesis nol tidak ditolak, bahwa tidak terdapat perbedaan rata-rata kedua kelas. Pada kolom mean difference tercantum rata-rata perbedaan mean skor selisih motivasi awal-motivasi akhir adalah -1,250 ini berarti kelompok Ekseperimen-2 memiliki rata-rata yang lebih baik dari kelompok Eksperimen-1, meskipun perbedaan ini tidak signifikan.

Temuan dalam penelitian ini sesuai dengan temuan penelitian Anesia Dyah Widayanti (2013) yang menemukan bahwa metode pembelajaran cooperative learning menimbulkan, suasana positif yang memberi kesempatan kepada siswa untuk menyenangi pelajaran. Melalui kegiatan-kegiatan yang menyenangkan ini siswa merasa lebih terdorong untuk belajar dan berpikir.

\section{SIMPULAN}

Berdasarkan data temuan dapat disimpulkan bahwa terdapat pengaruh yang signifikan penggunaan model pembelajaran kooperatif, baik tipe TPS maupun NHT, dibandingkan dengan penggunaan pembelajaran konvensional. Bila dibandingkan antara model pembelajaran TPS dan $\mathrm{NHT}$, ternyata tidak menyebabkan perbedaan yang signifikan pada hasil belajar. Sedangka pada aspek motivasi belajar siswa, Penggunaan model pembelajaran kooperatif, baik tipe TPS maupun $\mathrm{NHT}$ berpengaruh positif pada motivasi siswa dibandingkan dengan pembelajaran konvensional.

Berdasarkan kesimpulan penelitian, peneliti menyarankan agar dilakukan penelitian yang lebih komprehensif tentang model pembelajaran kooperatif untuk lebih menggali kekuatan dan kelemahannya. Mengingat pentingnya matematika bagi berkembangan berpikir siswa, guru dalam menyampaikan pelajaran matematika perlu memilih model pembelajaran yang tepat, yang dapat mendorong peserta didik untuk lebih aktif dan kreatif berpikir dalam kegiatan proses belajar.

Pemilihan model pembelajaran yang tepat dapat mempengaruhi keberhasilan dalam proses belajar mengajar dan meningkatkan motivasi siswa. Keaktifan dan kekreatifan peserta didik dalam proses belajar mengajar ini dapat meningkatkan daya tarik mata pelajaran matematika bagi siswa, sehingga mereka lebih mencintai matematika. 


\section{REFERENSI}

Arends, Richard. (1997). Classroom instruction and Management. New York:McGraw-Hill Company, Inc.

Daulay, Hamidah. ( 2013 ). Penerapan Pembelajaran Kooperatif Tipe Think Pair Share Untuk Meneningkatkan Hasil BelajarMatematika Kelas V SD Negeri 163099 Tebing Tinggi. Diambil 29 Juni 2015 dari situs : http://digilib.unimed.ac.id/.

Ibrahim,M., Rachmadiarti., Nur,M., \& Ismono. (2000). Pembelajaran Kooperatif. Surabaya: University Press.

Lie, Anita. (2005). Mempraktekkan Cooperative Learning di ruang-ruang kelas. Jakarta: Grasindo. Sardiman, A,M. (1990). Interaksi dan Motivasi Belajar Mengajar. Jakarta: Rajawali. Slameto. (2010). Belajar dan Faktor-Faktor yang mempengaruhinya. Jakarta: Rineka Cipta Sopyyev, Ylyas. (2013). Implementasi Pembelajaran Matematika dengan Menggunakan Model "Think-pair-share" pada Materi Fungsi Ditinjau dari Motivasi Belajar Siswa SMP Semesta. Skripsi. Pendidikan Matematika. FMIPA.UNNES.

Trianto. (2011). Model-model Pembelajaran Inovatif Berorientasi Konstruktivistik, Jakarta:Prestasi Pustaka.

Widayanti, Anesia Dyah. (2013). Pengaruh Model Kooperatif Tipe Numbered Head Together Terhadap Motivasi Dan Hasil Belajar Siswa Kelas VII di MTsN Karangrejo Tulungagung. Diambil 29 Juni 2015 dari situs : http://digilib.iain-tulungagung.ac.id/. 